Rafael Capurro on Hermann Rösch

\title{
Book review: Informationsethik und Bibliotheksethik. Grundlagen und Praxis
}

\section{Book details}

Hermann Rösch: Informationsethik und Bibliotheksethik. Grundlagen und Praxis. Berlin/Boston: de Gruyter 2021, 584 p. ISBN 978-3-11-051959-4.

\section{Reviewer:}

- Prof.em. Dr. Rafael Capurro

- Hochschule der Medien (HdM), Stuttgart, Germany

- Capurro Fiek Foundation for Information Ethics, $\underline{\text { http://www.capurro-fiek- }}$ foundation.org

- Distinguished Researcher at the Department of Information Science, University of Pretoria, South Africa.

- Founder: International Center for Information Ethics (ICIE), https://www.i-c-i-e.org \& International Review of Information Ethics (IRIE) https://informationethics.ca/

○ +49 - 721 - 98229 - 22, rafael@capurro.de, www.capurro.de 


\section{Overview}

Hermann Rösch, professor emeritus of Information Ethics at the Institute of Information Science, TH Köln / University of Applied Sciences, has published "Information Ethics and Library Ethics. Foundations and Practice" a primer in the German speaking world. It is the first comprehensive up-to-date presentation of both fields that are intimately related but have their own foundational and practical issues. The book starts with a short chapter on ethics as a philosophical discipline. Ethics is defined as the theoretical reflection on morals. With regard to law, it deals with its foundation and is its complement. There is a productive tension between ethics and law that might be a source of misunderstandings. There is also a tension inside ethics itself conceived as the search for universal and meta-historical principles and values but also dependent cultural and historical situations. In the introductory chapter the author discusses three kinds of ethical theories, namely, 1) virtue ethics, deontological ethics, and ultimate end ethics ("Gesinnungsethik"), 2) ethics of responsibility ("Verantwortungsethik") and utilitarianism and 3) discourse ethics. He analyzes the difference between general ethics and applied ethics as well as the one between personal ethics ("Individualethik") and institutional ethics ("Institutionenethik"). In the following (Chapter 3) the main issues of information ethics (IE) and library ethics (LE) (Chapter 4) are discussed.

Rösch gives a short account of the history of IE starting with Robert Hauptman and the author of this review who used this term in the late eighties, being already addressed in the Information Science field in the early eighties by Barbara J. Kostrewski and Charles Oppenheim. Although different terms such as media ethics, internet ethics or computer ethics were used it was IE that became predominant when dealing with the impact of information technology on society in the first decade of the new millennium. In Germany, it is Rainer Kuhlen, Jessica Heesen, and the author of this review who are pioneers in the field. The term media ethics ("Medienethik") was used to deal with ethical issues of mass media. One main issue in the field of IE dealt from scratch with information justice ("Informationsgerechtigkeit") arising from the Declaration of Principles of the World Summit on the Information Society (WSIS) that took place in Geneva (2003) and Tunisia (2005). It raised emancipatory aspects within normative ethical reflection based on a critical analysis of power structures in society looking for orientation and different options for action without a dogmatic foundation. It is not technology but humans who develop culturally embedded norms and values, that is to say, forms of life, as answers to the challenges of new technologies. The author sums up the different aspects of information ethics as descriptive, analytic, normative, emancipatory and critical ("aufklärende"). The following key issues of IE are dealt with in Chapter 3:

1) Freedom: including particularly: freedom of speech, information freedom, censorship and surveillance;

1) Justice: information justice, basic information supply ("Informationelle Grundversorgung"), digital divide;

2) Privacy: privacy protection, data protection, informational autonomy ("informationelle Sebstbestimmung"), data minimization, anonymity, transparency, surveillance;

3) Intellectual property and open access: copyright, open source, open access, decommodification, plagiarism;

4) Quality: information quality, misinformation, disinformation; and

5) Information ecology.

The second part of this chapter deals with a critical analysis of selected technologies such as: 1) search engines (indexing, ranking, data protection, marketing); 2) social networks (data protection and privacy), public and private sphere, hate speech; 3) personalization; 4) big data; 5) algorithms, AI; 5) cyber crime.

Chapter 4 deals with the field of LE whose history goes back to early twentieth century where issues of Library ethics were first raised by US public librarian Mary Plummer in her 1903 article "The Pros and Cons of Training for Librarianship". The article dealt with the need for a professional ethics. A number of decades 
later, in 1938, the American Library Association finally published its ethics code. According to the author, the reason why LE was not further developed until the eighties was due to the rise of IE, which was inclusive of the ethical issues of librarianship. The specificity of LE lies in its focus in the library as an institution which is also the case of similar fields such as archive ethics or museum ethics. All of them can be understood as subfields of IE. A key difference between LE and IE as well as related fields such as archive and museum ethics lies in the fact that the difference between individual ethics and institutional ethics can be clearly drawn. But general ethical issues as well as the main aspects dealing with descriptive, analytic, normative, emancipatory and critical ("aufklärende") issues mentioned above are relevant for LE as well. The author analyzes the ethical values in LE as described particularly by Michael Gorman and Wallace Koehler comparing them with the core values of the American Library Association and the values of IE with particular attention given to the individual ethical aspects as well as to the main fields of library practice.

He summarizes them as follows:

1) Selection, acquisition, licensing: freedom of information, freedom from censorship, neutrality, information quality;

2) Indexing: neutrality;

3) Transmission: neutrality, pluralism, authenticity and integrity;

4) Use: privacy, neutrality of treatment, freedom of information;

5) Delivery and other services: freedom of information, freedom from censorship; and

6) Management, organization, staff: service orientation, professionality, integrity, sustainability

The author analyzes and discusses specific ethical issues at length which means some 260 pages in the case of LE and some 170 pages for IE. I would like to highlight only one of them, namely information ecology ("Informationsökologie") that is dealt with in IE as well as in LE. The author of this review introduced this term in 1989. Thomas Davenport and Lawrence Prusak published their "Information Ecology" in 1997. Rainer Kuhlen used the term "knowledge ecology" ("Wissensökologie") in 2000. Fake news, disinformation and misinformation are the main concern of ethical, legal and political matters today. The same can be said regarding privacy protection, freedom from censorship, and information justice dealing with different kinds of digital divides, the predominance of global players and the spread of cyber war and cyber crime. Controversial issues of freedom of information arise from cultural and particularly from religious differences no less than from struggles for economic and political dominance and exploitation. In other words, IE and LE belong to the larger field of social and political ethics.

The author includes in the appendix several codes of ethics in the library field such as the IFLA Code of Ethics, the Code of Ethics of the American Library Association as well as two documents of German library associations.

As the author himself acknowledges, LE has not been a subject of research and practice among German librarians, research institutes and library associations. But awareness is rising.

An intercultural analysis of LE was initiated in 2005, led in IE by authors such as Charles Ess, Soraj Hongladarom and the author of this review, an analysis that remains, in this publication, a desideratum for future research. The reviewer wishes such an analysis a broad impact not only in German speaking countries but for which an English translation is needed. The sooner the better. 